International Research Journal of Management, IT \& Social Sciences
Available online at https://sloap.org/journals/index.php/irjmis/
Vol. 7 No. 6, November 2020, pages: 66-71
ISSN: 2395-7492
https://doi.org/10.21744/irjmis.v7n6.1010

\title{
The Science in Islamic Perspective
}

CrossMark

Muslimah ${ }^{\text {a }}$

Hamdanah ${ }^{b}$

Nina ${ }^{\mathrm{c}}$

Article history:

Submitted: 27 August 2020

Revised: 18 September 2020

Accepted: 09 October 2020

\section{Keywords:}

human life;

Islamic perspective;

knowledge;

library research;

science;

\begin{abstract}
This study aimed to discuss the importance of science and the Islamic perspective's position controller. The data collection of this research was carried out using the library method. Therefore, it is included in library research, preceded by collecting printed and electronic references, sourced from books and articles relating to the meaning, scope, and position of knowledge. We continued to review and explore the connections. The results explain the importance of science from the perspective of Islamic studies, namely that it cannot be separated between human life and progress/civilization. In this context, science and technology are among the branches of knowledge that provide great benefits and benefits to human survival in this world and the hereafter. Islam has glorified people who master science. Even since the Prophet Muhammad was sent to become a prophet, he always exemplified and reminded him to strive for it because he expected Allah SWT's pleased.
\end{abstract}

International research journal of management, IT and social sciences ()$^{2} 2020$.

This is an open access article under the CC BY-NC-ND license (https://creativecommons.org/licenses/by-nc-nd/4.0/).

\section{Corresponding author:}

Muslimah,

Lecturers of IAIN Palangka Raya, Indonesia.

Email address: muslimah.abdulazis@iain-palangkaraya.ac.id

\footnotetext{
${ }^{a}$ Lecturers of IAIN Palangka Raya, Indonesia

${ }^{\text {b }}$ Professor of IAIN Palangka Raya, Indonesia

${ }^{c}$ Postgraduate Student of IAIN Palangka Raya, Indonesia
} 


\section{Introduction}

The number of verses of the Koran that view knowledgeable people in a high and noble position and the Prophet's hadiths encourage them to continue studying. It shows that the teachings of Islam, as reflected in the Koran, are very thick with nuances related to science to become an important characteristic of Islam itself. Ghulsaniy (1991), exemplifies the emphasis on science (science), the Koran, and the Sunnah, which invite people to seek and gain knowledge and wisdom and place knowledgeable people at high degrees.

Apart from the Qur'anic verses that position knowledge and knowledgeable people very special, the Koran also encourages prayer so that knowledge is added, and say, my Lord, add to me knowledge. It is in this connection that the concept of reading (the universe), as a vehicle for adding knowledge to be very important, as enshrined in QS alAlaq verses 1-5. Asshabun nuzul this verse was narrated by Bukhari, his sahih hadith from Aisyah: "In the beginning, Rasulullah receives his revelation through true dreams. Every time he dreams, in the afternoon that dream comes true. From that moment on, he was eager to be alone (in prayer).

$\mathrm{He}$ also went to the Hira cave which is outside the city of Mecca (about $6 \mathrm{~km}$ from the city center), sat several nights in it with the necessary provisions. When the supplies ran out, the Prophet returned to his wife Khadija's house, to return to take supplies. And so on and on until the Prophet received an unexpected revelation. While he was sitting in the cave, the angel Jibril came, asking the Prophet Muhammad to read. "Read", said Jibril. The Prophet replied "I can't read". So, Jibril hugged the Prophet tightly so that the Prophet felt unhappy. After releasing his embrace, Jibril returned to order the Prophet to read and the Prophet replied "I cannot read". Jibril returned to hug the Prophet very tightly. After releasing his embrace, Jibril recited the first five verses of this surah al - ' A la (HR. Bukhari). (Kathir, 2019).

This verse is a source of motivation for Muslims to never stop studying by studying Allah's creations to maintain a high position before Allah (Bakar, 2003), it also means that Allah's fear will animate all activities of human life to do righteous deeds (Akbar, 2019). Thus appears that the belief that coincided with science will lead to charity. (Aslan, 2019; Basir, 2020; Mizani et al., 2020; Hamdanah, 2018). According to Islam, it is only natural that Nurcholis Madjid states that faith and scientific deeds form a triangle of this solid life pattern to mediate between faith and charity (Muslimah, 2016; Larijani \& Zahedi, 2004; Al-Karasneh \& Saleh, 2010; Munawar, 2014). Although pursuing knowledge is an obligation for a Muslim, both male and female. However, humans are still reluctant to do it (Muslimah, 2016), so they must first explore how Allah views them as knowledgeable people. This study aims to discuss the importance of science and the position that controls it from an Islamic perspective.

\section{Materials and Methods}

This research used the method of literature (library research). Literature study or literature can be defined as a series of activities relating to collecting library data, reading and taking notes, and processing study materials (Muslimah, 2016; Aslan, 2017; Zed, 2004; Liu et al., 2005). Collecting data in this study conducted by examining and exploring several books, print and electronic, as well as other data sources that are relevant to the study of science and its scope; as well as regarding the position of science, people who study, and people who are knowledgeable in an Islamic perspective, who are analyzed by expert opinion and the results of previous relevant studies, connected with the AlQur'an and Hadith.

\section{Results and Discussions}

Discussing this paper, it starts with getting to know what science is. The word "science" in Arabic comes from the verb fi'il' alima, the mashdar (abstract noun) form of ' alima-ya'lamu, which means to know or to know, and in the form of fa'il (the perpetrator's noun form). (subject) 'alim is a person who knows/has the knowledge, commonly' scholars, and in the form of maf'ul (which becomes the object), knowledge is called ma'lum or what is known (Muslimah, 2016). In English, science is usually equated with the word science, while knowledge is knowledge. In Indonesian, the word science is generally defined as filter science, which is often interpreted as science, although conceptually, it refers to the same meaning. Meanwhile, according to its scope, science is a general term to refer to all scientific knowledge, which is seen as a unanimity; in this sense, science refers to the science in general (science in general). (Poerwadarminto, 1982; Gallagher, 2000; Zohdi, 2017).

Muslimah, M. ., Hamdanah , H. ., \& Nina , N. . (2020). The science in Islamic perspective. International Research Journal of Management, IT and Social Sciences, 7(6), 66-71. https://doi.org/10.21744/irjmis.v7n6.1010 
In terms of Islam, science refers to each field of knowledge that studies a particular subject (Çoruh, 2020). In this sense, science means a special branch of knowledge, such as the science of tauhid, fiqh, interpretation, and so on. (Langgulung, 1986). According to Imam al-Ghazali, experience in the broadest sense includes ilmusyar'iyyah and ghairu syar'iyyah science. Syar'iyyah science is the knowledge that he comes from the Prophet and must be demanded and studied by every Muslim of these Prophets, al - Ghazali classified them into Ghairu syar's category iyyah. (alThusi, n.d.).

Imam al-Ghazali also classified science into two groups: the science of fraud a'in; and the science of fardu kifayah. Ilmu fardu 'ain is the knowledge of how to do deeds according to the shari'ah, with all its branches, as covered by Islam's pillars. Simultaneously, the science of fardu kifayah is any science that cannot be ruled out in upholding worldly affairs: medical science, arithmetic for buying and selling, agricultural science, political science, helpful sewing, and important sciences for efforts to maintain world affairs. (al-Thusi, n.d.).

Perspektive philosophy of science, the science of understanding shall include at least three things: knowledge, activities, and methods (Syar'i, 2020). In the first case, science is often called knowledge. According to Ziauddin Sardar, he also argues that science or science is a way of studying nature objectively and systematically and science is a human activity (Syar'i, 2020). Thus, science in Islamic studies, namely science, contains a comprehensive and continuous meaning and values that cannot be separated. In this context, science and technology are between branches of knowledge that provide great benefits and benefits to human survival in the world and the afterlife.

Seeking and studying is an obligation for a Muslim, both male and female. Prophet, Making the activity of studying and knowledge required by the Muslims to uphold their religious affairs, as liabilities fardlu 'ain for every Muslim. The knowledge that is fardlu ' ain is the knowledge that everyone who is aqil baligh is obliged to practice it, including knowledge of aqidah, carrying out Allah's orders, and leaving His prohibitions. (al-Thusi, n.d.). Mentioned in HR. Abu Dawud which means "From Anas bin Malik RA. He said Rasulullah SAW said: Demanding knowledge is obligatory for every Muslim. (Majah, n.d.). al-Iraqi commented on this hadith: "According to Ahmad bin Hanbal, al-Baihaqi and other scholars are dha'if ". However, al-Suyuti comments: "Although many scholars me $\mathrm{n}$ - dha'if - this tradition, it will be, al-Mizzi believes this hadith hasan. The reason al-Mizzi: because this tradition has many paths so that its validity rose to hasan". (Al-Suyuthi, n.d.).

As for other sciences that are needed by Muslims in their lives, including fardlukifayah. It means that all Muslims will sin if none of them is engaged in some knowledge, even though they need it. They were not free from sin so that one of them fulfilled that obligation. (al-Thusi, n.d.).

Rasulullah SAW., Motivating his companions is not only limited to studying religion related to shari'ah. He also called on them to explore other knowledge and expertise that would benefit Muslims, namely the understanding that law requires fardlu kifayah. In essence, human beings who make the knowledge as their aspirations and compete to achieve it have pioneered a path that makes it easier for them to go to heaven. As the Hadith means:

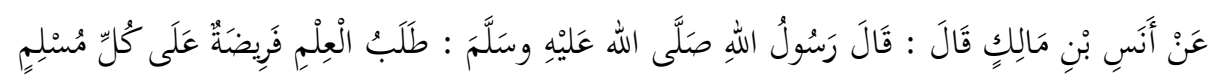

Meaning:

From Abu Hurairah RA. Said: Rasulullah saw. said: Whoever takes the path to study knowledge, Allah makes it easy for him to go to heaven " (Narrated by Muslim, al-Turmudzi, Ahmad, Ibn Majah, and al-Darimi). (HR. Muslim,alTurmudzi, Ahmad, Ibnu Majah, dan al-Darimi). (Muslim, 2004: al-Turmudz, 2003; Hanbal, t.th; Majah, t.th; Darimi, 1470).

Describing this Hadith, Imam Nawawi reminded that virtue when traveling in search of knowledge obtained someone, if his work at the Shari'ah sciences and aims to God. Although this is an absolute prerequisite in every worship, the scholars have the habit of reminding it because some people are often careless in seeking knowledge. Especially young people are looking for experience, they often forget their goals and intentions. (Al-Nawawi, 1329).

This hadith has been researched and has been traced into mu'jam al-hadith using pieces of the pronunciation After tracing the information obtained in mu'jam volume 3 page 5 is as follows: from the mu'jam information, the author refers to the hadith book and information is obtained from the book Sunan Al-Darimi Kitab Muqaddimah hadith number 24. According to Ibnu Hajar, the word طَرِيًْا expressed in the form nakirah (indefinite), as well as the word means the science that covers all the way or ways to get the science of religion, either slightly or banyak. So when linked with the first passage down which the letter al-'Alaq, "اقَرَ" Means" read, "so to get the knowledge, you have to 
read a lot. For example, Allah created the seven layers of the heavens and the seven layers of the earth, all of which contain knowledge.

سَهُّلَ اللَّهُ لَهُ طَرِيقًا (Allah make it easy for him the path) that Allah makes it easy for him the road in the hereafter or ease her way in the world by giving guidance to him to do good deeds that can pass it to heaven. It contains good news for people who study that Allah makes it easy for them to seek and get it because studying is one way to heaven.

Al-Maraghi explained that those who fear Allah and fear Him and obey His punishment are only people who know about the greatness and power of Allah over whatever things He wills and that He does whatever He wants. Because a person who knows about it, he is sure about Allah's punishment for anyone who acts against Him. So he is afraid and terrified of Allah because he is afraid of being punished by Him.

Verse, traditions, and atsar above can be clearly understood that science is easier for people heading to heaven. It is easy to understand because Iwith knowledge, a person knows the correct creed, ways of worshipping properly, and forms of noble morals. Knowledgeable people also know things that can destroy the principle of tawhid, destructive things. A reward of worship, and also understand the destructive nature and morals that need to be avoided. Everything would take him to $\mathrm{s}$ in the afterlife, even prosperity in this world.

When Muslims do their study together, Allah sends them sakinah (tranquillity), grants them grace full of tenderness and compassion, and the angels always surround them and call them people who are pleased with Allah. Therefore, a person who wants to study religion seriously until he understands it is a sign that Allah wants goodness. Goodness will be obtained by a person when seeking knowledge is accompanied by positive and beneficial goals and intentions for humans and life, or in his religion's language, with an open plan because of Allah. Prophet Muhammad SAW. Strongly denounced and forbade the claimant of knowledge only for popularity, power, and worldly splendor (Al-Darimi, 1470). The position of knowledge in Islam is so high that the Messenger of Allah, SAW. Said that background includes three things whose rewards are not interrupted after the owner dies. As the following hadith.

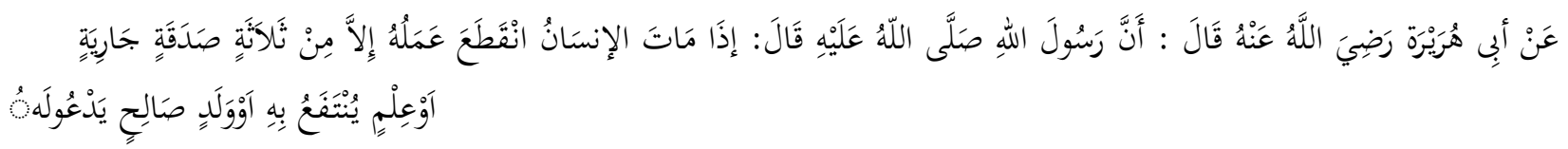

Meaning: From Abu Hurairah . that Rasulullah saw. said: When someone dies, his charity will be cut off, except for three things, except for alms, or knowledge that is used, or pious children who pray for him. (Narrated by Muslim, alTirmidhi, al-Darimi, Abu Dawud, al-Nasa'i, and Ahmad). (Muslim, 2004, p. 125) (al-Turmudz, 2003, p. 660) (AlDarimi, 1470 H, p. 148) (Hanbal, t.th, p. 372.)

This hadith has been investigated and has been traced to the Qur'an al-hadith by using pieces of pronunciation after outlined obtained information in the Qur'an vol 3 page 336, their information that three things are always rewarded by God in a person even though he is dead, that is; 1) almsgiving Jariyah (waqf which has long been used); 2) useful knowledge, and 3) prayers that a godly child asks for his parents. In connection with this discussion is helpful knowledge, namely knowledge taught by one person (scholar) to others and writing (essay) intended by the author to be used by others.

\section{Conclusion}

Science in Islamic studies' perspective is comprehensive and continuous, and its value cannot be separated. The position of people who are knowledgeable in Islamic teachings is considered very important, even since the Prophet Muhammad was sent to be a Prophet, he reminded his friends and followers always to study. However, Rasulullah SAW. It also reminded him to do it in the corridor of expecting the pleasure of Allah SWT. The benefits of knowledge can only be obtained if it is accompanied by good and correct intentions and goals when demanding it. With good and right choices, the knowledge acquired is expected to be useful. The rewards will continue to flow and raise the degree of those who do it, even though the owner has passed away, as Allah's promise conveyed by the Prophet Muhammad.

Muslimah, M. ., Hamdanah, H. ., \& Nina , N. . (2020). The science in Islamic perspective. International Research Journal of Management, IT and Social Sciences, 7(6), 66-71. https://doi.org/10.21744/irjmis.v7n6.1010 
Conflict of interest statement

The authors declared that they have no competing interests.

Statement of authorship

The authors have a responsibility for the conception and design of the study. The authors have approved the final article.

Acknowledgments

We are grateful to two anonymous reviewers for their valuable comments on the earlier version of this paper. 


\section{References}

Akbar, A. (2019). Islam-science relation from the perspective of post-revolutionary Iranian religious intellectuals. British Journal of Middle Eastern Studies, 46(1), 104-122.

Al-Darimi, I. A.-D.-S. (1470 H). Sunan al-Darimi (Vol. Juz I). Dar al-Fikr.

Al-Karasneh, S. M., \& Saleh, A. M. J. (2010). Islamic perspective of creativity: A model for teachers of social studies as leaders. Procedia-Social and behavioral sciences, 2(2), 412-426. https://doi.org/10.1016/j.sbspro.2010.03.036

Al-Nawawi, I. S.-N.-F. (1329 H). Shaheh Muslim Bi Syarhi al-Nawawi (Vol. Juz VI). Beirut: Dar al-Fikr.

Al-Suyuthi, J. a.-D. (t.th). al-Jarh wa al-Ta'dil (Vol. Juz I). Beirut: Dar al-Fikr.

Al-Suyuthi, J. a.-D., n.d. al-Jarh wa al-Ta'dil, 1st ed. Dar al-Fik, Beirut.

al-Thusi, A.H.M. bin M. bin A., n.d. Ihya 'Ulumiddin, Beirut: Darul Kutub al-Ilmiyah. Darul Kutub al-Ilmiyah, Beirut.

Al-Turmudz, A. '.-S. (2003). Sunan al-Turmudzi (al-Jami’a al-Turmudzi) (Vol. Juz V). Semarang: Makatabah wa Mathba'ah Toha Putra.

Aslan, A. (2017). Pumping Teacher dalam Tantangan Pendidikan Abad 21. Muallimuna, 2(2), 89-100.

Aslan, A. (2019). Peran Pola Asuh Orangtua di Era Digital. Jurnal Studia Insania, 7(1), 20-34.

Bakar, O. (2003). Reformulating a comprehensive relationship between religion and science: an Islamic perspective. Islam \& Science: Journal of Islamic Perspective on Science, 1(1).

Basir, A. (2020). Hasil Uji Plagiasi" The Parenting of Parents Toward Their Children Education According to AFQuran Perspective".

Çoruh, H. (2020). Relationship Between Religion and Science in the Muslim Modernism. Theology and Science, 18(1), 152-161.

Gallagher, S. (2000). Philosophical conceptions of the self: implications for cognitive science. Trends in cognitive sciences, 4(1), 14-21. https://doi.org/10.1016/S1364-6613(99)01417-5

Ghulsaniy, M. (1991). Filsafat Sains Menurut al-Qur'an. Mizan, Bandung.

Hamdanah, H. (2018). Psychological impacts on interfaith families in palangkaraya in educating their children. The Open Psychology Journal, 11 .

Hanbal, I. A. (t.th). Musnad Imam Ahmad (Vol. Juz II). Beirut: Dar al-Fikr.

Kathir, I. (2019). Tafsir Al-Quran. Independently Published.

Langgulung, H. (1986). Manusia dan pendidikan. Jakarta: Pustaka Al-Husna.

Larijani, B., \& Zahedi, F. (2004, December). Islamic perspective on human cloning and stem cell research. In Transplantation Proceedings (Vol. 36, No. 10, pp. 3188-3189). Elsevier. https://doi.org/10.1016/j.transproceed.2004.10.076

Liu, X., Bollen, J., Nelson, M. L., \& Van de Sompel, H. (2005). Co-authorship networks in the digital library research community. Information processing \& management, 41(6), 1462-1480. https://doi.org/10.1016/j.ipm.2005.03.012

Majah, I., n.d. Sunan Ibnu Majah, bab 'a’linu al- nikah, juz 1, no. 1895.

Mizani, H., Basir, A., Giri, S., Juhaidi, A., \& Aslan, A. (2020). Understanding Islamic Education Model for Children of Early Married Families in South Kalimantan. Talent Development \& Excellence, 12(2), 4365-4374.

Munawar, N. (2014). The Islamic perspective approach on plant pigments as natural food colourants. Procedia-Social and Behavioral Sciences, 121, 193-203. https://doi.org/10.1016/j.sbspro.2014.01.1120

Muslimah, M. (2016). Nilai religious culture di lembaga pendidikan.

Poerwadarminto, S.W. (1982). Kamus Lengkap Inggris-Indonesia. Hasta, Bandung.

Syar'i, A. (2020). Filsafat Pendidikan Islam., Ed. Mahyuddin, Ed. Narasi Nara, Palangka Raya.

Zed, M. (2004). Metode peneletian kepustakaan. Yayasan Obor Indonesia.

Zohdi, A. (2017). Islamic scientific epistemology in Al-Jabiri perspective. International journal of linguistics, literature and culture, 3(5), 26-35.

Muslimah , M. ., Hamdanah , H. ., \& Nina , N. . (2020). The science in Islamic perspective. International Research Journal of Management, IT and Social Sciences, 7(6), 66-71. https://doi.org/10.21744/irjmis.v7n6.1010 